\title{
OPERATYWNO-HEURYSTYCZNE KSZTAŁCENIE DLA ZDROWIA W KONCEPCJI FILOZOFICZNEJ JULIANA ALEKSANDROWICZA
}

\begin{abstract}
Streszczenie. W tekście podjęto zagadnienie wartości operatywno-heurystycznego prozdrowotnego kształtowania postaw inspirowanego filozoficzną koncepcją Juliana Aleksandrowicza. Tło rozważań stanowią obecne we współczesnej kulturze tendencje rozwoju ultratechnologii. Z uwagi na odcięcie się medycyny od korzenia filozofii zachodzi konieczność przewartościowania dziedzictwa neopozytywistycznego oraz redefinicji pojęć: „zdrowie” i „choroba”. Problem decyzyjny „życie albo śmierć”, definiowany w kategoriach dysjunkcji, narzuca nowy sposób interpretacji pojęć moralnych. Idea autokreacji w procesie przywracania dobrze stworzonej natury jest w tej koncepcji równoważona przez subiektywne poczucie zdrowia, odnoszone do szerokiego kontekstu fizycznego i psycho-duchowego, społecznego, środowiskowego. Myśl ta znalazła odzwierciedlenie w przyjętej przez Juliana Aleksandrowicza koncepcji holistycznie ujmowanego zdrowia jako wartości moralnej.
\end{abstract}

Słowa kluczowe: skuteczność; heurystyka; filozofia zaangażowana; witalność; zdrowie

1. Wstęp. 2. Julian Aleksandrowicz - ambasador humanizmu w medycynie. 2. Ekologizm otwarty system prozdrowotny. 4. Przedmiot nauk o zdrowiu - współczesna dyskusja.

5. Zakończenie.

\section{WSTĘP}

Intensywne w XX wieku poszukiwania skuteczności w procedurach ochrony życia i zdrowia stanowiły konsekwencję traumatycznych wojennych doświadczeń oraz przewrotu cywilizacyjnego, skutkującego społecznymi patologiami: technologizacją, utylitaryzmem, komercjalizacją, reifikacją i wyobcowaniem człowieka. Toczący się dyskurs wokół problemów egzystencjalnych był odpowiedzią na pilną potrzebę redefinicji kategorii przynależnych zdrowiu oraz rewizji obowiązującego w nauce i praktyce klinicznej neopozytywistycznego 
modelu medycyny. Spór dotyczący samego pojęcia „zdrowie”, przez World Health Organization (WHO) definiowanego holistycznie jako „pełny dobrostan (dobre samopoczucie) fizyczny, umysłowy i społeczny, a nie tylko nieobecność choroby czy kalectwa" (Solik 2003, 6), doprowadził do wykrystalizowania się dwóch prymarnych stanowisk: twardego - w modelu medycyny naukowej oraz miękkiego - rewolucji naukowo-humanistycznej w medycynie.

Pierwsze podejście, krytyczne w stosunku do wizji zdrowia rozumianego jako well-being, z uwagi na nieprecyzyjność pojęcia, wyrażało zaniepokojenie możliwościami łatwego, niefrasobliwego, a nawet szalbierskiego, niecnego wykorzystywania słabości i nadużywania ludzkiego zaufania, prowadzącego do przekraczania standardów medycyny naukowej. Natomiast propagatorzy holistycznej wizji świata w powrocie do kanonu antycznego humanizmu widzieli szansę na zjednoczenie w medycynie różnorodnych pól problemowych, zwłaszcza personalizmu uwzględniającego inkluzję podmiotową jednostek. Poza sporem pozostawało jednak jedno niekwestionowane zagadnienie, wiążące oba stanowiska: konieczność skupienia uwagi na człowieku. W przeciwieństwie do „twardej” szkoły niemieckiej, w której przedmiotem zabiegów medycznych była choroba organizmu - nie pacjent (Biegański 1894) - polscy inicjatorzy rewolucji humanistycznej w medycynie (m.in. Władysław Biegański, Antoni Kępiński, Andrzej Szczeklik, Tadeusz Kielanowski, Kazimierz Imieliński, Kazimierz Dąbrowski) zalecali przyjęcie strategii uwzględniającej indywidualizm pacjenta, prowadzącej do stopniowego zastępowania paternalizmu w lecznictwie relacjami personalnymi. Pierwowzory ich konceptualizacji można było w PRL-u rozpoznać w aktywistycznych programach państwowego systemu służby zdrowia (Brzeziński 1995; Fijałek 1995; Jagiełłowicz 2021).

Chociaż programy polskich szkół medycznych, w których eksponowano czynnik głęboko ludzki, w XX wieku stanowiły cenny wkład w rozwój zachodniej filozofii medycyny, to $z$ uwagi na pogłębiającą się świadomość jedności wszechrzeczy koncepcja 
humanizmu w medycynie wymagała korekty na miarę przewrotu kopernikańskiego.

\section{JULIAN ALEKSANDROWICZ - AMBASADOR HUMANIZMU W MEDYCYNIE}

Przełom w zakresie tworzenia multidyscyplinarnego, zintegrowanego ujęcia zdrowia rozumianego w szerokim kontekście społecznym i środowiskowym (w przeciwieństwie do antropocentryzmu) został dokonany dopiero przez Juliana Aleksandrowicza ${ }^{1}$. Jako protoplasta zaangażowanej filozofii ochrony zdrowia ${ }^{2}$ domagał się ukorzenienia medycyny w filozofii (Szyszkowska 1989; Jagiełlowicz 2021). Twierdził, że syntetyzujące poznanie „służy przetrwaniu przez wymuszone prawem ewolucji doskonalenie się" (Aleksandrowicz, Duda 1988, 23), z nieodłącznymi w tym doskonaleniu: samowiedzą aksjologiczną, autoafirmacją i podnoszeniem jakości życia, manifestującymi się $\mathrm{w}$ personalizmie, kreatywizmie, pacyfizmie i ekologizmie. Poddawał krytyce mechanicyzm, chorobocentryzm, utylitaryzm i komercjalizację usług, znamionujące kulturę medyczną współczesnego świata; traktował je jako skutek odcinania się medycyny od jej korzenia, czyli pielęgnowanych w filozofii wysokich wartości moralnych.

1 Julian Aleksandrowicz (1908-1988), krakowski profesor nauk medycznych, lekarz-hematolog, filozof. Znany jako porucznik „Doktor Twardy” z bohaterskich czynów z czasów II wojny światowej. Założył w Krakowie III Klinikę Chorób Wewnętrznych, przekształconą w Klinikę Hematologii, gdzie w praktyce zawodowej zajmował się ekologiczną profilaktyką białaczek i chorób cywilizacyjnych. Aktywnie uczestniczył w pracach stowarzyszeń rozwijających działalność prozdrowotną. Kontynuując posłannictwo lecznicze, zaangażował się w działalność arteterapeutyczną, pacyfistyczną, społeczną (Aleksandrowicz 2001; Aleksandrowicz, Stawowy 1992; Rożnowska 2012).

2 Koncepcję otwartego systemu prozdrowotnego Aleksandrowicza przedstawiłam w monografii Juliana Aleksandrowicza „poszukiwania filozofii ochrony zdrowia” (Jagiełłowicz 2011), która pozostaje jak dotąd jedyną pełną rekonstrukcją poglądów tego lekarza i filozofa. 
W sformułowanym przez Aleksandrowicza dylemacie wyczuwa się subtelny odcień wyrzutu czynionego kolegom - lekarzom, którzy podporządkowali się medycynie ujętej w karby wysokiej specjalizacji i rozwiniętej technologii, zapominając o właściwym posłannictwie o uleczaniu: „Czy hołdować zasadom Hipokratesa i poszukiwać w każdej dostępnej dziedzinie życia sposobów ulżenia cierpieniom (skoro medycyna jest bezsilna), czy podporządkować się redukcjonistycznej doktrynie i neopozytywistycznym zasadom pragmatycznej medycyny, kiedy specjalista nie widzi człowieka w środowisku, w jakim zachorował, a jedynie chory narząd, którego uszkodzenie powoduje niekiedy zgon?” (Aleksandrowicz 1987, 5).

Jądro kryzysu etycznego przejawiającego się w „wypaczonym stosunku człowieka do człowieka i człowieka do żywej przyrody" (Aleksandrowicz 1979, 7) Aleksandrowicz lokowal w produkcie zdegenerowanego mózgu: w dominacji praw rynku. Stał na stanowisku, że informacje kodowane i przechowywane w pamięci nie mogą służyć przetrwaniu, bowiem „mózg ludzki jest żywą tkanką podlegającą innym prawom niż maszyna. (...) Mózg uszkodzony wykazuje tendencje regresu. Produkty myśli uszkodzonego mózgu nie mogą służyć dobru, lecz jego antynomii. W tej fazie znalazł się świat" (Aleksandrowicz 1987, 197). Poszukiwał metody wspomagającej człowieka w wysiłkach pokonywania patogennych czynników, aby mógł się on odwrócić od „myśli, słów i czynów wiodących do antynomii: fałsz - brzydota - zło" (Aleksandrowicz, Duda 1988, 19). W owej pracy nad sobą, w podnoszeniu do lepszej jakości życia, nie chodziło o „zewnętrzne atrybuty osoby ludzkiej” (Aleksandrowicz 1987, 14) i zabiegi powierzchniowe, dokonywane na „somatycznej, precyzyjnej, biologicznej "maszynie»" (Aleksandrowicz 1987, 17), polegające na remontowaniu uszkodzonego ciała, usprawnianiu go, autostylizacji oraz estetyzacji wizerunku, lecz o dogłębną, istotową przemianę podmiotu żyjącego w symbiozie ze środowiskiem: o „relacje między osobami i ich właściwościami” (Aleksandrowicz 1987, 14). 
Panaceum na bolączki chorującego świata Aleksandrowicz spodziewał się znaleźć w rewolucji ,naukowo-etycznej”, transformującej psychikę człowieka. Przemianę zapewnić miało przejście „z modelu »erudycyjno-kontenerowego «, a więc wiedzy biernej, nagromadzonej w pamięci ucznia, na rzecz modelu »operatywno-heurystycznego", w którym uczeń nabywa umiejętności samodzielnego przyswajania wiedzy" (Aleksandrowicz 1987, 89). Nie tyle rezygnacja z rewolucji „naukowo-technicznej”, co właściwe, realizowane w duchu ideałów humanizmu jej wykorzystanie stanowiło w tej koncepcji podstawę reformy polegającej na wdrażaniu idei kształcenia dla zdrowia. W myśl założenia, że „wciąż żywe idee mają charakter ponadczasowy” (Aleksandrowicz, Duda 1988, 246), dowodził, iż odradzająca się w dobie kryzysu ekologiczno-etycznego starogrecka zasada jedności wszechrzeczy „dopiero dziś, w oparciu o współczesną technikę obliczeniową, może być cennym instrumentem badawczym" (Aleksandrowicz, Skotnicki 1983, 6). Dla potwierdzenia tej tezy, w ramach programu obejmującego analizę uwarunkowań zdrowia-choroby, wspólnie z cybernetykiem Józefem Kosseckim zakładali „Banki Czynników Zagrożenia” i „Banki Czynników Ochrony Przetrwania” (Aleksandrowicz 1987; Kossecki 1974).

Nadzieję na rozwiązanie współczesnych problemów ludzkości Aleksandrowicz pokładał w ekologizmie (Aleksandrowicz, Skotnicki 1983) - systemie jednoczącym rewolucję humanistyczną z rewolucją naukowo-techniczną (Aleksandrowicz 1974). Dowodzi1: „Ponieważ nie jest możliwe proste, linearne sumowanie wiedzy, konieczne jest przyjęcie innej metodologii - systemowej" (Aleksandrowicz, Duda 1988, 25). Dostatecznym uzasadnieniem dla poszukiwań filozofii ochrony zdrowia (Aleksandrowicz 1975) był dla niego alarmujący wzrost chorób, zwłaszcza cywilizacyjnych, o których wiadomo, że są zależne „nie tylko od stopnia rozwoju cywilizacji technicznej, ale od anomalii (...) środowiska, wyzwalanej najczęściej działalnością człowieka" (Aleksandrowicz 1987, 7). Nie wyrażał także zgody na doskonalenie maszyn służących zabijaniu oraz na dysproporcje 
istniejące pomiędzy nikłą liczbą osób uczących się sztuki leczenia a liczbą ludzi szkolących się w śmiercionośnych „sztukach”. Krytyczna sytuacja, w której znajduje się współczesny człowiek, wymaga radykalnej decyzji w kwestii wyboru pomiędzy życiem a śmiercią. Zdrowie powiązane węzłem ochrony z pokojem zyskuje tutaj znaczenie symboliczne w myśl twierdzenia, że „pokój jest tym dla rodzaju ludzkiego, czym zdrowie dla pojedynczego człowieka" (Aleksandrowicz 1987, 184). Zatem profilaktyka nie może się ograniczać do czynności demilitaryzacyjnych, lecz winna przyjmować postać troski: nieinteresownego zaangażowania w proces ochrony struktur i funkcji organizmów przed niszczycielskimi czynnikami, bowiem w obliczu zagrożenia totalną zagładą, przed jaką stoi świat, problem nie dotyczy już akcydentalnie wszczynanych wojen-potyczek, ale kategorycznego rozwiązania dysjunkcji „życie albo śmierć” przez globalne opowiedzenie się po stronie życia (Aleksandrowicz, Hameed 1989).

Powołana przez Aleksandrowicza w ubiegłym wieku szkoła filozofii ochrony zdrowia zyskała poparcie polskiego środowiska intelektualistów. Na wielu obszarach działalności naukowej, edukacyjnej, klinicznej, arteterapeutycznej aktywnie uczestniczyli oni w jego operatywno-heurystycznym projekcie, zafascynowani ideą podnoszenia jakości życia w oparciu o samowiedzę aksjologiczną i kreację wyzwoloną z pancerza stereotypów, przesądów i dogmatów naukowych. Aleksandrowicz współpracował z Włodzimierzem Sedlakiem, twórcą oryginalnej koncepcji bioelektroniki, z Marią Szyszkowską, autorką filozofii codzienności, a z Kazimierzem Dąbrowskim, twórcą teorii dezintegracji pozytywnej, powołał do istnienia Krakowski Oddział Towarzystwa Higieny Zdrowia Psychicznego. Współpracował także z satyrykiem i publicystą Janem Izydorem Sztaudyngerem, który był jego pacjentem - leczył metodą „terapii przez śmiech”. W jego klinice poetyckie warsztaty arteterapeutyczne prowadziła Wisława Szymborska, która m.in. przyczyniła się do ozdrowienia Haliny Poświatowskiej. Terapię, którą określę mianem „mowy ciała”, podjął we współpracy z Wrocławskim Teatrem „Laboratorium” Jerzego 
Grotowskiego (Aleksandrowicz 1987). Na polu pedagogiki, wraz z pacjentką Reginą Knapik, opracował futurologiczne zasady wychowania w aspekcie zdrowia społecznego (Aleksandrowicz, Knapik 1968). Natomiast w ramach działalności arteterapeutycznej otworzył w Żegiestowie-Zdroju ośrodek naukowo-leczniczy, gdzie m.in. z Henrykiem Gaertnerem i Tadeuszem Natansonem eksperymentował $\mathrm{z}$ dźwiękami, wykorzystując je $\mathrm{w}$ charakterze stymulatorów zdrowia (Osóbka 2002).

Projekt wielopoziomowego i wielowymiarowego systemu prozdrowotnego Aleksandrowicza stanowi emergentną całość. Jego otwarta formuła stwarza możliwość odkrywania i kształtowania innowacyjnych form istnienia, dokonywania esencjalnych transformacji, pobudza do autentycznego poznania i rozwoju, do kreatywnego posługiwania się sprawnościami moralnymi w środowisku ustrukturyzowanym - fizycznym, psychoduchowym, społecznym, przyrodniczym, kosmicznym. System ów pokonuje bezwład i hipokryzję doktrynerów, w myśl twierdzenia jego twórcy, że „proces wzbogacania się o wiedzę musi dokonywać się ustawicznie. Umysł ludzki bowiem odkrywa wciąż nowe prawdy, wyprzedzając biurokratyczną pragmatykę" (Aleksandrowicz 1987, 36).

\section{EKOLOGIZM - OTWARTY SYSTEM PROZDROWOTNY}

Obok otwartości systemowej oraz faktu uznawania przez naukę własnej dyskursywności pojawiła się współcześnie nowa forma jej potwierdzania i legitymizacji: operatywność rozumiana jako skuteczność globalnego oddziaływania socjoekonomicznego i przekształcania - przez samą filozofię generalnie nieakceptowana, poza wyjątkami zinstrumentalizowanych jej subdyscyplin ${ }^{3}$. Admiracja dla nauk ścisłych oraz dla logiki formalnej doprowadziła do powszechnej

3 Na przykład filozofii stosowanej czy coachingu filozoficznego (Leśniak 2018; Jagiełłowicz 2021). 
dyskredytacji filozofii i w ogóle humanizmu. Krytykowane przez Aleksandrowicza stereotypy myślowe powstałe w okresie rewolucji przemysłowej i naukowo-technicznej, a wraz z nimi infantylizacja życia, uśpienie czujności i płytki materializm, skalują obraz technologii, wyolbrzymiając jej znaczenie. Schematy te stanowią potwierdzenie tezy, że „nauka stała się symbolem, a nawet fetyszem naszych czasów. Jest źródłem wielkich nadziei - także nadziei irracjonalnych" (Aleksandrowicz, Duda 1988, 26).

Ujęta w katalogu megatrendów ${ }^{4}$, obserwowana we współczesnym świecie tendencja rozwojowa dotycząca przechodzenia od epoki przemysłowej (wykorzystującej pracę fizyczną) do postindustrialnej (informacyjnej), związana z postępem ultratechnologii jako technologii zaawansowanej (Naisbitt 1997), wywiera znaczący wpływ nie tylko na środowisko naturalne, ale również oddziałuje na wewnętrzne dymensje człowieka, zwłaszcza na jego reaktywność uczuciowo-emocjonalną i wrażliwość oraz świadomość przejawianą w zakresie preferowanego systemu wartości. Bezpośrednim i podstawowym skutkiem owego ukonstytuowania osobowego są stosowane formy aktywności prozdrowotnej. Zatem w niespotykanych dotąd warunkach, gdy „nauka i jej pochodna - technika - odgrywają w życiu jednostek i świata rolę ogromną, nieporównywalną z jakąkolwiek epoką w przeszłości” (Aleksandrowicz, Duda 1988, 246), przed filozofią ochrony zdrowia otwiera się nowa perspektywa badawcza, opozycyjna w stosunku do „twardego” modelu medycyny zapoznającej wartość podmiotowego istnienia.

4 Prekursorem pojęcia „megatrendy” jest John Naisbitt, amerykański futurolog. W opublikowanej w 1982 roku książce Megatrends. Ten New Directions Transforming Our Lives (Naisbitt 1982; 1997) zastosował opracowaną przez siebie metodę badawczą, polegającą na wnikliwej obserwacji społeczeństwa amerykańskiego, systematycznej lekturze czasopism i analizie zjawisk społecznych. Na tej podstawie wyodrębnił kierunki rozwoju i przemian współczesności. Z uwagi na fakt, iż większość opisanych przez niego zjawisk i procesów znamionuje uniwersalizm, w literaturze przedmiotu megatrendy jako podstawowe tendencje rozwojowe, określające kształt nadchodzącej przyszłości, przyjmują miano trendów globalnych, ogólnoświatowych, cywilizacyjnych (Stacewicz 1996). 
Idea równoważenia nowych technologii odruchami ludzkimi, na określenie której John Naisbitt ukuł terminus technicus „ultratechnologia/ultrastyk", symbolizuje balans pomiędzy technologiami a rzeczywistością psychoduchową, mający umożliwić człowiekowi regulację skutków cywilizacyjnych (zwłaszcza negatywnych), a więc przywrócić stan harmonijnego rozwoju w zdrowiu, w omawianym przez Aleksandrowicza aspekcie „równowagi w zakresie somatopsychicznej struktury osoby ludzkiej, społeczności międzynarodowej, całej biosfery oraz kosmosfery" (Aleksandrowicz 1987, 17). Wyodrębniony przez Naisbitta ruch rozwoju osobowości jako rekompensujący bezosobowy charakter technologii stanowi dobry przykład formuły ultratechnologia/ultrastyk (Naisbitt 1997). Zdaje się też potwierdzać tezę Aleksandrowicza, że „dopóki (...) zjawisko życia trwa, ma zdolność samosterowania dla utrzymywania się w homeostazie" (Aleksandrowicz, Duda 1988, 24).

W obliczu postępujących, również $\mathrm{w}$ następstwie rozwoju ultratechnologii, problemów współczesnego „chorującego świata”, odnoszących się do sfery życia jednostkowego, społecznego i środowiskowego, sformułuję problem: czy zależność ultratechnologia/ ultrastyk jest uniwersalna? $Z$ perspektywy koncepcji Aleksandrowicza istotne jest, czy postulowane sprzężenie należy traktować jako odruchowe i mające powszechne, jedyne i skuteczne zastosowanie w procesie rozwiązywania nurtujących ludzkość problemów związanych z technicyzacją świata. W sytuacji narastających zagrożeń i patologii współczesności (wymienię tylko alienację człowieka, reifikację życia, utylitaryzm, degradację naturalnego środowiska) trudno jest podzielać entuzjazm Naisbitta, gdy reakcję ultrastyku na ultratechnologię niefrasobliwie - jak odnoszę wrażenie - porównuje on do starogreckiego ideału równowagi, a technologię i ludzki potencjał traktuje jako „wielkie wyzwanie i przygodę ludzkości” (Naisbitt 1997, 63). W moim przekonaniu sprzężenia ultratechnologia/ ultrastyk są we współczesnym świecie reakcjami obronnymi, często zautomatyzowanymi. Tymczasem Aleksandrowicz interpretował 
rozwój w kategoriach esencjalizmu i witalności, jako zapośredniczony w samowiedzy aksjologicznej, spełniający się w aktach wolitywnych i w autokreacji.

O wiele bardziej pojemna i dyskursywna wydaje się teza Naisbitta, $\dot{z}$ e „postęp technologiczny rzadko odbywa się drogą prostej ekstrapolacji; na ogół przebiega jako część zmiennej dynamiki złożonych wzorców i procesów" (Naisbitt 1997, 64), nieuchronnie wiedzie do namysłu nad naturą ludzkiego reagowania, również charakteryzującego się niestałością, falującego i wahadłowego. Stąd wyprowadzić można konstatację o wiążących zarówno postęp, jak i ludzką reaktywność uwarunkowaniach, a także o dynamizmie samej zależności ultratechnologia/ultrastyk, które winny być rozpoznawane i umiejętnie kształtowane. Przesłanka ta koresponduje z Aleksandrowiczowską koncepcją „mechanizmów rządzących dynamiką zachorowalności” (Aleksandrowicz 1987, 20) - rola medycyny jest badanie ich i takie ukierunkowywanie, aby przejawy życia mogły się manifestować w zdrowiu.

Istotne kryteria przyjaznej dla życia koncepcji spełnia operatywno-heurystyczny model kształcenia, w którym integrowana jest wiedza wielu dyscyplin, wykorzystywane są metody konwersji języków, poszukiwana jest właściwa wykładnia dla zadań optymalizujących troskę o zdrowie w zdeterminowanych kulturowo i zróżnicowanych na wielu poziomach bytowania środowiskach. Profil uczonego wpisującego się w ramy tego otwartego systemu prozdrowotnego - jak dowodził Julian Aleksandrowicz, nawiązując do wypowiedzi Włodzimierza Sedlaka - „stoi »ponad rezerwuarem informacyjnym, a nie na jego brzegu«, gdyż (...) heurystyczna teoria staje się dziś wielokrotnie ważniejsza od typowych weryfikacji dawnego stylu. Nie jest bowiem »ważne, czy teoria jest prawdziwa«. Istotne jest, by mobilizowała i dynamizowała badacza do intelektualnego wysiłku" (Aleksandrowicz 1987, 88). Ta wypowiedź, wyprzedzająca swój czas, zawiera wybitnie uwspółcześniony przekaz, że kształcenie polegające na sumowaniu wiadomości jest dla rozwoju bezużyteczne, bowiem 
funkcję gromadzenia i przetwarzania informacji z większym powodzeniem i możliwościami niż pojemność i potencjały ludzkiego mózgu spełniają serwery obsługujące bazy danych wraz z obejmującymi je systemami zarządzania. Przechowywane w formie elektronicznej, zgromadzone i sformatowane zbiory ustrukturyzowanych, na bieżąco aktualizowanych danych ustawicznie uczestniczą w procesie realizacji zadań ewidencyjno-sprawozdawczych, statystycznych, administracyjnych, archiwizacyjnych.

Kształcenie winno przyjąć postać odmienną niż gromadzenie informacji. Winno kształtować postawy, pobudzać do samodzielnego myślenia i tworzenia syntez zgodnie $z$ duchem rewolucji naukowo-humanistycznej, inspirującej do kreowania zintegrowanej multidyscyplinarnej wiedzy i sztuki oraz stosowania ich w praktyce wynalazczej w celu rozwiązywania problemów i podnoszenia jakości życia ludzi oraz biosfery, z którą rodzaj ludzki jest sprzężony zwrotnie (Aleksandrowicz 1987). W zgodzie $\mathrm{z}$ tą potrzebą zaimplementowany przez Aleksandrowicza do filozofii ochrony zdrowia model operatywno-heurystyczny obejmuje algorytm rozwiązywania zadań wynalazczych, opracowany przez Gienricha Saułowicza Altszullera. Ów zbiór wskazówek uporządkowanych w logicznie spójny system i uwzględniających czynniki ludzkie, zwany metodą projektowania ARZW, aktywizuje czynności umysłowe, składające się na procesy twórcze, przy równoczesnym systematycznym i ekonomicznym sterowaniu przebiegiem rozwiązywania problemów (Altszuller 1972; Góralski 1980; Kozielecki 1969).

Wzorce pracy twórczej i wynalazczej dostarczane przez heurystykę (Antoszkiewicz 1982) Aleksandrowicz wdrożył do projektowania zdrowia i pokoju, rozumianych w szerokim zakresie. Model ten jako otwarty wykorzystuje operatywną koncepcję wykładni, z jednej strony umożliwiającą rekonstrukcję treści w oparciu o wyróżnione jednostkowe subiektywne poczucie zdrowia, zapośredniczone w mikroopowieści ulokowanej w immanencji, $\mathrm{z}$ drugiej - bierze pod uwagę interpretację, zgodnie z którą dokonana powinna być rewizja 
podstawy wewnętrznej z uwagi na sparametryzowane i sformalizowane fakty zobiektywizowanej choroby. Pozyskana kompletna wiedza ma służyć projektowaniu przez osobowe jednostki przyszłości, pokonywaniu ograniczeń i progów, transformowaniu i kreowaniu siebie i świata; jako taka zawiera skuteczne środki do realizacji wielorakich zadań. Opracowany zgodnie z tymi kryteriami plan winien zapewniać sprawną realizację wyznaczonego celu. Obejmuje on procedury postępowania obowiązujące przy rozwiązywaniu problemów, tablicę sprzeczności problemowych oraz wykaz zasad, prawideł, norm służących do usuwania owych sprzeczności.

W świetle założeń modelu operatywno-heurystycznego, opracowanego przez Aleksandrowicza, nie wyłącznie analityczne i spekulatywne, ale bezpośrednie i dogłębne rozpoznanie sytuacji współczesnego świata jest warunkiem koniecznym rozwiązywania nurtujących ludzkość problemów. Rozpoznanie to także w optyce opracowanej przez Kazimierza Dąbrowskiego teorii dezintegracji pozytywnej stanowi fundament transformowania osobowego istnienia (Dąbrowski 1979; 1989), rozumianego w fenomenologii Maxa Schelera w "charakterze podmiotu wartości wyższych od pożytku” (Scheler 1997, 194), na które należy nałożyć wysiłek „przekraczania” (Scheler 1987). Rozpoznanie sprzyja zatem aktywności prozdrowotnej, którą w naukach o zdrowiu opisuje się jako pielęgnowanie, wzmacnianie i potęgowanie służące wzrastaniu i rozwojowi (Bulicz, Murawow 2003). Tak interpretowany fenomen troski o zdrowie przyjmuje postać wartości moralnej, znajdując dla egzystencji ludzkiej metafizyczne uzasadnienie, analogicznie do sensu uprawnienia człowieka do owej troski i zobowiązania go do niej, wykładanych w bioetyce personalizmu chrześcijańskiego (Wrężel 2007). Z uwagi na godność człowieka jako osoby niezbywalne i nienaruszalne prawo daje mu nie tylko podstawę, ale i przywilej starannej dbałości o siebie - w konceptualizacji Józefa Tischnera: ze względu na fakt doświadczania życia ukorzenionego w najwyższym boskim bycie (Tischner 1998b). Istotą wyzwolenia z egotyzmu, przekroczenia zewnętrzności, otwarcia się 
na Drugiego jest bezpośrednie przeżywanie, obecność, która nie krzywdzi, nie zadaje bólu (Tischner 1998a).

Aleksandrowicz w duchu personalizmu o subtelnym odcieniu metafizycznego interpretowania tajemnic życia i w perspektywie holistycznej konceptualizował najwyższą, w jego przekonaniu, uniwersalną zasadę: moralne uprawnienie i zobowiązanie do troski o zdrowie. Podstawę aksjologiczną w jego koncepcji stanowi teza, że „ponadczasowym prawem każdej ludzkiej działalności jest służenie dobru swoich najbliższych przez troskę o dobro powszechne. (...) Ta dyrektywa, wiodąca do prawdy o dobrej jakości życia, dotyczyć powinna każdej dziedziny ludzkiego działania" (Aleksandrowicz 1987, 35-36). W wewnętrzności „drugiego” (rozciągniętego na całe ludzkie i kosmiczne środowisko) dostrzegał roszczenie domagające się życia. „Ludzkość stoi obecnie przed koniecznością zasadniczego wyboru. Istnieje następująca alternatywa: kontynuować szalony pęd do samounicestwienia albo odnaleźć drogę prowadzącą do przeżycia i przyszłego rozwoju" (Aleksandrowicz, Hameed 1989, 11). Obowiązkiem człowieka, jak twierdził, jest odpowiedzieć na to wyzwanie biofilitycznie. Tymczasem wbrew racjonalnym argumentom oraz pilnej potrzebie przeciwdziałania zagrożeniom „podatnością na zło, naszą nieumiejętnością rozwiązywania sprzeczności bez eliminowania bądź uszkadzania przeciwnika, krótkowzrocznością, brakiem poczucia odpowiedzialności i nieczułością na cierpienia każdej formy życia na Ziemi" (Aleksandrowicz, Stawowy 1992, 7-8) ludzie przyczyniają się do postępującej degeneracji świata. W świecie „atomowych gigantów i etycznego skarlenia" (Aleksandrowicz 1987, 14) przetrwanie jest możliwe dzięki pozytywnym relacjom oraz przeciwstawianiu się wszelkim formom zła, które za sprawą kryzysu etycznego wiedzie do kryzysu ekologicznego (Aleksandrowicz 1987).

Zachowując dystans wobec teorii usprawiedliwiających relatywizm moralny, Aleksandrowicz przedstawił twardą definicję antynomii dobra: działań, które „dodają cierpień do cierpień egzystencjalnych” (Aleksandrowicz 1987, 21). Był przeświadczony, że człowiek może 
skutecznie zapobiegać uwarunkowanym ekologicznie chorobom, jednak pod warunkiem zjednoczenia ideałów humanizmu ze zintegrowanymi naukami. W ich jedności widział szansę na osiągnięcie "egalitaryzmu biologicznego i etycznego" (Aleksandrowicz 1987, 43). Przyjął, że kształtowanie postaw dokonuje się we wszelkich wymiarach egzystencji. Istnieje zatem potrzeba włączenia nauczania prozdrowotnego do duchowego programu wychowania Kościoła katolickiego jako posiadającego w Polsce wysoki moralny i pedagogiczny autorytet. $\mathrm{W}$ dokumencie wystosowanym w dniu 14 czerwca 1973 roku do kardynała Karola Wojtyły, ówczesnego arcybiskupa krakowskiego, w imieniu pracowników Kliniki Hematologicznej w Krakowie zwrócił się z propozycją włączenia do kościelnego nauczania tematyki prozdrowotnej. Prośbę motywował pilną potrzebą korygowania międzyludzkich stosunków, które w społeczeństwie stanowią antynomię miłości bliźniego (Aleksandrowicz, Stawowy 1992)5 i domagają się natychmiastowego reagowania oraz takich konstruktywnych, odkrywczych, pozbawionych przemocy rozwiązań, dzięki którym dokonane zostanie przeistoczenie świata chorującego w zdrowiejący.

\section{PRZEDMIOT NAUK O ZDROWIU - WSPÓŁCZESNA DYSKUSJA}

W cywilizacji ultratechnologicznej problemy odnoszące się do istoty zdrowia rozwiązywane są mechanistycznie, zgodnie ze wciąż obowiązującym neopozytywistycznym wzorcem, który ujmuje medycynę $\mathrm{w}$ kategoriach chorobocentryzmu, redukcjonizmu, depersonalizacji (Płonka-Syroka 2001). Nie umniejszając roli medycyny naukowej $\mathrm{w}$ procesie diagnostyczno-terapeutycznym na poziomie cielesnej egzystencji pacjenta, zauważyć należy, że interpretacja ta zamyka

5 Jan Paweł II w liście z 17 sierpnia 1988 roku wyróżnił Aleksandrowicza osobistymi podziękowaniami za monografie: Sumienie ekologiczne oraz U progu medycyny jutra (Aleksandrowicz, Stawowy 1992). 
w obrębie skostniałych ram myślenia dyskurs aksjologiczny toczący się wokół zagadnień zdrowia. Wprawdzie w prewencyjnej, predykcyjnej i personalizującej medycynie nowej generacji (Pasowicz 2013) oficjalnie głosi się jedność psychofizyczną człowieka, jednak w praktyce lekarskiej przyjmowana jest linia proceduralna zgodna $z$ doktryną mechanistycznego biologizmu.

Problem jedności wszelkich ludzkich dymensji powraca nie tylko w sformułowanej przez WHO definicji zdrowia. Jest on także obecny $\mathrm{w}$ debacie dotyczącej podwójnej moralności zinstytucjonalizowanej medycyny, redukującej pacjenta do chorobowego przypadku (Demel 2011). Jak dowodził Aleksandrowicz, „Lekarze, dzięki dzisiejszej technologii, potrafią co najwyżej sprawnie »remontować« skalpelem uszkodzone fragmenty biologicznej maszyny ludzkiej, ale nie umieją dać człowiekowi filozofii, zapewniającej psychiczny spokój, równowagę, a niekiedy radość życia nieodzowną dla zdrowia" (Aleksandrowicz, Duda 1988, 16). Jaskrawym przejawem współczesnej technologizacji medycyny jest medykalizacja choroby, legitymizująca procedury usuwania z pola lekarskiego zainteresowania problemów egzystencjalnych człowieka, które do końca XVIII wieku stanowiły integralną część profesjonalnego lekarskiego nakazu troski (Płonka-Syroka 2001)6.

Kultura medyczna kształtowana w duchu depersonalizacji, chorobocentryzmu, medykalizacji choroby, mechanicyzmu biologicznego wzmacnia proces instrumentalizowania jednostkowej egzystencji. Waloryzuje cechy, struktury i funkcje organizmu oraz zdolności człowieka według kryteriów sprawności, wymienialności oraz użyteczności, przyczyniając się w ten sposób do wyjałowienia życia z wartości psychoduchowych. Czy jest zatem możliwa taka

6 Na planie społecznym mechanizm ten jest powszechnie wykorzystywany na przykład w socjologii medycyny, w medycynie pracy, w procesie wyznaczania progów referencyjnych (norm i wartości), sporządzania tablic nozologicznych. Szczególnie dotkliwie odczuwany jest w sytuacjach dotyczących degradacji, wykluczenia czy izolacji, na przykład osób niepełnosprawnych, upośledzonych psychicznie, seniorów (Rurawski 1988). 
kategoryzacja zdrowia, która pomaga, aby tych „subtelnych wartości nie zagubić" (Demel 2011, 11), lecz wzmacniać już istniejące i pozyskiwać nowe? Z problemem tym zmierzył się Julian Aleksandrowicz, przedkładając kolejnym pokoleniom wizję życia i zdrowia, które nie są constans. Po śmierci Aleksandrowicza w nauce i praktyce klinicznej podstawy ekologizmu realizował jego wierny uczeń Aleksander Skotnicki (Aleksandrowicz, Skotnicki 1983). Dziś, niestety, innowacyjne tezy otwartego systemu prozdrowotnego Aleksandrowicza odeszły w zapomnienie. Jedynie w piśmiennictwie Andrzeja Bałandynowicza, Ełły Bulicz, Igora Murawowa i Marii Szyszkowskiej można odnaleźć ślady pogłębionej refleksji na temat założeń tej koncepcji (Bałandynowicz 2021; Bulicz, Murawow 2003; Szyszkowska 1989).

Teoremat odrodził się wprawdzie w stosunkowo młodej dziedzinie wiedzy: waleologii (łac. valeo - ,jestem zdrów”)" otwartej na odkrywczą i twórczą aktywność człowieka w zakresie rozwoju jego całego potencjału psychofizycznego i duchowego oraz w poszanowaniu naturalnego środowiska. Waleologia jako zintegrowany zbiór multidyscyplinarnych nauk o fundamentalnych zasadach zachowywania, wzmacniania i potęgowania zdrowia podejmuje problem metodologicznych podstaw ochrony zdrowia ludzi i potrzeby zmiany strategii opieki zdrowotnej z chorobocentryzmu na badanie personalne - etiologii i mechanizmów zdrowia jednostkowego (Brekhman 1980; Brekhman, Dardymov 1969). Jednak w moim przekonaniu dyskurs na temat istoty zdrowia przerodził się w spór formalny dotyczący zmian terminologicznych. Wiktor Porfirjewicz Petlenko na określenie nauk o zdrowiu zaproponował pojęcie „sanologia” (łac. sanus - „zdrowy”, „poprawny”, ,prawidłowy”), zdrowie interpretując w charakterze braku chorób (Petlenko 2001). Tymczasem Y.P. Lisitsin określił ją mianem „medycyny eliminacji” (Lisitsin 1973; Lisitsin, Semenov 1983). Jako nauka o zdrowiu społecznym (Jabłoński 1998)

7 Termin „waleologia” wprowadził na początku lat 80. XX wieku Israel Itsokovich Brekhman (Brekhman 1990). 
sanologia stanowi obecnie doktrynę antropocentryczną, obejmującą procedury stosowania środków zapobiegawczych oraz wykorzystywania mechanizmów biospołecznych do walki organizmu z chorobą. Maciej Demel powołując się na opinie uznanych autorytetów w tej dziedzinie, Ełły Bulicz oraz Igora Murawowa, pisał przed dziesięciu laty, że nauki o zdrowiu „nic fundamentalnie nowego, co uzyskałoby uznanie specjalistów, na razie dać nie mogą" (Demel 2011, 9). Dziś, po upływie kolejnej dekady, nic się w tej kwestii nie zmieniło - w cywilizacji ultratechnologicznej spór o przedmiot medycyny zatacza koło i powraca do punktu wyjścia, "malując swoiście batalistyczny obraz przedsięwzięć medycznych" (Jagiełłowicz 2011, 40). Choroby na powrót stały się centralnym obiektem zainteresowania medycyny (Bulicz, Murawow 2006).

\section{ZAKOŃCZENIE}

Z uwagi na obecne w XIX oraz na przełomie XX i XXI wieku poszukiwania skuteczności w procedurach ochrony życia i zdrowia, ultratechnologizację świata oraz odcięcie się medycyny od korzenia filozofii - skutkujące rozlicznymi kryzysami społeczno-etycznymi i ekologicznymi - w nowych warunkach cywilizacyjnych zachodzi potrzeba wzmożonego namysłu nad istotą życia, przewartościowania dziedzictwa neopozytywistycznego z jego mechanicyzmem, chorobocentryzmem i redukcjonizmem biologicznym oraz redefinicji pojęć: „zdrowie” i „choroba”, a także opracowania nowego modelu kształtowania postaw prozdrowotnych. W odpowiedzi na dyskurs toczący się wokół problemów egzystencjalnych współczesnego chorującego świata i we współpracy z licznymi przedstawicielami nauki, filozofii, sztuki, a także z Kościołem katolickim i wszystkimi ludźmi dobrej woli, w polskiej myśli humanistycznej zadania tego podjąı się żyący w ubiegłym stuleciu Julian Aleksandrowicz.

Aleksandrowicz był przekonany, że w sytuacji zagrożenia zagładą definiowany w kategoriach dysjunkcji problem decyzyjny „życie albo 
śmierć" narzuca nowy sposób interpretacji pojęć moralnych. Jego zdaniem jedynym rozwiązaniem tej alternatywy wykluczającej jest radykalne opowiedzenie się po stronie życia - tak w teorii, jak też w praktyce społecznej. W paradygmacie „nowej medycyny” tego lekarza-humanisty i społecznika idea autokreacji w procesie przywracania dobrze stworzonej natury jest równoważona przez subiektywne poczucie zdrowia, uwzględniające inkluzję podmiotową jednostek i odnoszone do szerokiego kontekstu psychoduchowego, społecznego oraz środowiskowego. W modelu tym zdrowie indywidualnej jednostki ludzkiej jest tym, czym pokój dla społeczeństwa. $Z$ tego też powodu w pierwszej kolejności od stanu lekarskiego należy wymagać troski i odpowiedzialności zarówno za zdrowie jednostki (rozumianej nie wyłącznie w kategoriach „maszyny biologicznej”), jak również za pokonywanie patologii społecznych, wśród których najdotkliwszą wydaje się wojna.

Tworząc multidyscyplinarne, zintegrowane ujęcie zdrowia rozumianego $\mathrm{w}$ szerokim kontekście społecznym i środowiskowym (w przeciwieństwie do antropocentryzmu), Aleksandrowicz zrewolucjonizował nie tylko podejście do medycyny, ale też do samego człowieka - do jego potrzeby doskonalenia się na poziomie samowiedzy aksjologicznej, afirmacji i podnoszenia jakości życia, manifestujących się w personalizmie, kreatywizmie, pacyfizmie, ekologizmie. Można zatem uznać Aleksandrowicza za protoplastę prozdrowotnego otwartego systemu o kwalifikacji zaangażowanej filozofii. Jego propozycja przełamania kryzysu etycznego stanowi metodę kształtowania postaw, wspomagającą człowieka w wysiłkach pokonywania patogennych czynników. Zgodnie $\mathrm{z}$ reformą polegającą na wdrażaniu idei kształcenia dla zdrowia, rewolucję „naukowo-etyczną” transformującą psychikę ludzką zapewnić może rezygnacja z modelu przyswajania wiedzy biernej na rzecz modelu „operatywno-heurystycznego”, w którym człowiek nie tylko uczy się, myśląc samodzielnie, ale jest również odkrywcą i kreatorem w życiu własnym i w historii świata. 
Toczący się jeszcze w ostatniej dekadzie XX wieku w obrębie waleologii dyskurs na temat istoty życia i zdrowia oraz metod pokonywania patologii i ograniczeń współczesnego świata przerodził się niestety w spór formalny, dotyczący zmian terminologicznych. Dzieło zaangażowanej filozofii ochrony zdrowia prof. Juliana Aleksandrowicza wciąż zatem oczekuje na godnych kontynuatorów.

\section{BIBLIOGRAFIA}

Aleksandrowicz, J. (1975). Wiedza stwarza nadzieje. Warszawa: Wiedza Powszechna.

Aleksandrowicz, J. (1987). Nie ma nieuleczalnie chorych. Łódź: Państwowe Wydawnictwo „Iskry”.

Aleksandrowicz, J. (1988). Sumienie ekologiczne. Warszawa: Wiedza Powszechna. Aleksandrowicz, J. (2001). Kartki z dziennika Doktora Twardego. Kraków: Wydawnictwo Literackie.

Aleksandrowicz, J. (red.). (1974). Rewolucja naukowo-bumanistyczna. Warszawa: Wiedza Powszechna.

Aleksandrowicz, J., Duda, H. (1988). U progu medycyny jutra. Warszawa: PZWL. Aleksandrowicz, J., Hameed, A. (1989). Filozoficzne i historyczne przestanki elementologii medycznej. W: J.W. Dobrowolski, S.B. Vohora (red.), Ekologizm w ochronie zdrowia, 11-15. Wrocław - Kraków: Ossolineum.

Aleksandrowicz, J., Knapik, R. (1968), Futurologiczne aspekty wychowania i nauczania młodzieży uniwersyteckiej a problemy zdrowia społecznego. Znak, 11-12(173-174), 1478-1493.

Aleksandrowicz, J., Skotnicki, A. (1983). Zmierzch nibilizmu terapeutycznego oraz renesans ekologizmu czyli systemowej koncepcii świata. W: [red. nieznany], Propozycja kompleksowej terapii u chorych na stwardnienie rozsiane, 5-7. Kraków: Krakowski Oddział Polskiego Towarzystwa Walki z Kalectwem.

Aleksandrowicz, J., Stawowy, E. (1992). Tyle wart cztowiek... . Lublin: Wydawnictwo Lubelskie.

Altszuller, H. (1972). O uzdolnieniach wynalazczych. Prakseologia, 41, 121-144. Antoszkiewicz, J. (1982). Metody heurystyczne. Warszawa: PWE.

Bałandynowicz, A. (2021). Cztowiek czastkq Wszecbsiwiata: Rozważania antropologiczno-flozoficzne i flozoficznoprawne. Warszawa: Wydawnictwo Difin.

Biegański, W. (1894). Logika medycyny czyli zasady ogólnej metodologii nauk lekarskich, Warszawa: Drukarnia K. Kowalewskiego. 
Brekhman, I.I. (1980). Man and biologically active substances. The effect of drugs, diet and pollution on health. Oxford: Pergamon Press.

Brekhman, I.I. (1990). Waleologia - nauka o zdrowiu [w jęz. rosyjskim]. [brak miejsca wydania]: Wydawnictwo Kultura Fizyczna i Sport.

Brekhman, I.I., Dardymov, I.V. (1969). New substances of plant origin which increase nonspecific resistance. Annual Review of Pharmacology, 9(1), 419-430.

Brzeziński, T. (1995). Rozwój nauk medycznych i ksztatcenia lekarzy w Polsce w XIX i pierwszej potowie XX wieku. W: T. Brzeziński (red), Historia medycyny, 413423. Warszawa: Wydawnictwo Lekarskie PZWL.

Bulicz, E., Murawow, I. (2003). Od istoty zdrowia do jego diagnostyki i ukierunkowanego potegowania. W: E. Bulicz (red.), Potegowanie zdrowia. Czynniki, mechanizmy i strategie zdrowotne, 7-19. Radom: Wydawnictwo Politechniki Radomskiej.

Bulicz, E., Murawow, I. (2006). Czy profilaktyka medyczna prowadzi do zdrowia? Radom: Wydawnictwo Politechniki Radomskiej.

Dąbrowski, K. (1979). Dezintegracja pozytywna. Warszawa: PIW.

Dąbrowski, K. (1989). W poszukiwaniu zdrowia psychicznego. Warszawa: PWN.

Demel, M. (2011). Zdrowie: studium teoretyczne na przełomie XX i XXI stulecia. Zdrowie i spoteczeństwo, 1, 9-25.

Fijałek, J. (1995). Medyczno-spoteczne tradycje organizacyjne i naukowe w opiece zdrowotnej w XIX i XX wieku. W: T. Brzeziński (red), Historia medycyny, 383-412. Warszawa: Wydawnictwo Lekarskie PZWL.

Góralski, A. (1980). Twórcze rozwiązywanie zadań. Warszawa: PWN.

Jabłoński, L. (1998). Sanologia: nauka o zdrowiu społeczeństwa. Warszawa: WSRL. Jagiełłowicz, A.B. (2011). Juliana Aleksandrowicza „poszukiwania flozofii ochrony zdrowia". Wrocław: Wydawnictwo Lena.

Jagiełłowicz, A.B. (2020). Wartość i różnica w teorii subiektywnego zdrowia. W: P. Korobczak (red.), Filozofia XLV. Kryzys wartości - wartośc kryzysu, 111-127. Wrocław: Wydawnictwo Uniwersytetu Wrocławskiego.

Jagiełłowicz, A.B. (2021). Zaangażowana filozofia ochrony zdrowia. Filozofia i nauka. Studia filozoficzne i interdyscyplinarne, 9(1), 337-355.

Kossecki, J. (1974). Cybernetyka kultury. Warszawa: PIW.

Kozielecki, J. (1969). Rozwiq̨zywanie problemów. Warszawa: PZWL.

Leśniak, P. (2018). Filozofia tu i teraz. Ontologia procesu jako podstawa filozoficznego coachingu. Studia Philosophiae Christianae, 54(3), 111-147.

Lisitsin, Y.P. (1973). Organizacja ds. Higieny Spotecznej i Opieki Zdrowotnej [w jęz. rosyjskim]. Moskwa: [brak wydawcy]. 
Lisitsin, Y.P., Semenov, L.P. (1983). W kwestii socjologii medycyny. Sowiecka Stużba Zdrowia [w jęz. rosyjskim], 6, 27-34.

Naisbitt, J. (1982). Megatrends. Ten New Directions Transforming Our Lives. New York: Warner Books.

Naisbitt, J. (1997). Megatrendy. Dziesięć nowych kierunków zmieniających nasze życie. Poznań: Wydawnictwo Zysk i S-ka.

Osóbka, P. (2002). Wspomnienia z mojej pracy w Żegiestowie. W: B. Mściwujewska-Kruk (red.), Almanach Muszyny, 161-167. Muszyna: Towarzystwo Miłośników Ziemi Muszyńskiej.

Pasowicz, M. (2013). Medycyna nowej generacji. W: M. Pasowicz (red.), Zdrowie i medycyna-wyzwania przysztości, 85-95. Kraków: Oficyna Wydawnicza AFM.

Petlenko, V.P. (2001). Studia waleologiczne: zdrowie jako wartość ludzka [w jęz. rosyjskim]. Petersburg: [brak wydawcy].

Płonka-Syroka, B. (2001). Wstęp. W: B. Płonka-Syroka (red.), Choroba jako zjawisko spoteczne i historyczne, 3-8. Wrocław: Oficyna Wydawnicza Arboretum.

Rożnowska, K. (2012). Uleczyć świat. O Julianie Aleksandrowiczu. Kraków: Wydawnictwo Emilia.

Rurawski, J. (1988). Presja spoteczna a samotnośc. W: M. Szyszkowska (red.), Samotność i osamotnienie, 19-38. Warszawa: Instytut Wydawniczy Związków Zawodowych.

Scheler, M. (1987). Pisma z antropologii filozoficznej i teorii wiedzy. Warszawa: PWN.

Scheler, M. (1997). Resentyment a moralność. Warszawa: Wydawnictwo Czytelnik.

Solik, A. (2003). Międzynarodowe standardy zdrowia i praw reprodukcyjnych oraz seksualnych. W: Z. Dąbrowska (red.), Międzynarodowe standardy zdrowia i praw reprodukcyjnych oraz seksualnych a ich realizacja w Polsce, 5-28. Warszawa: Sekretariat Pełnomocnika Rządu ds. Równego Statusu Kobiet i Mężczyzn.

Stacewicz, J. (1996). Megatrendy a strategia i polityka rozwoju. Warszawa: Wydawnictwo Elipsa.

Szyszkowska, M. (1989). Filozofia prawa i filozofia cztowieka. Warszawa: Instytut Wydawniczy Pax.

Tischner, J. (1998a). Filozofia dramatu. Wprowadzenie. Kraków: Wydawnictwo Znak.

Tischner, J. (1998b). Spór o istnienie cztowieka. Kraków: Wydawnictwo Znak.

Wrężel, M. (2007). Pacjent. W: A. Muszala, (red.), Encyklopedia bioetyki. Personalizm chrześcijański, 424-433. Radom: Polskie Wydawnictwo Encyklopedyczne. 


\title{
OPERATIVE-HEURISTIC HEALTH EDUCATION IN JULIAN ALEKSANDROWICZ'S PHILOSOPHY
}

\begin{abstract}
This paper addresses the problem of employing a heuristic approach to examine the concept of health. The first to address this issue was Julian Aleksandrowicz, who developed the concept of a "new medicine", which I will call "engaged philosophy". The background for the discussion is given by postmodernist tendencies in contemporary culture, characteristic of a civilisation transforming at the level of ultra-technology and information. This paper highlights the necessity to reevaluate the Enlightenment and Neo-positivist heritage, as well as to redefine the key notions of life, death, health, and illness. The decisive problem of "life or death", defined according to these mutually exclusive categories, demands a new way of interpreting the moral categories attributed by Aleksandrowicz to the concept of a "healthy life". The idea of self-creation in the process of the "restoration of well created nature" is, according to him, equivalent to the category of "subjective health" broadly understood as psychophysical, social, spiritual, and economic health.
\end{abstract}

Keywords: effectiveness; heuristics; engaged philosophy; vitality; health

\footnotetext{
ALINA BERNADETTA JAGIEŁŁOWICZ

Uniwersytet Wrocławski, Instytut Filozofii

(University of Wrocław, Institute of Philosophy, Poland)

ORCID https://orcid.org/0000-0001-6168-3798

alina.jagiellowicz@uwr.edu.pl

DOI 10.21697/spch.2021.57.A.09

${ }_{\text {OPEN }} \partial_{\text {ACCESS }}$ (C) $\underset{\mathrm{BY}}{\mathrm{O} \text { ND }}$

Tekst jest udostępniany na zasadach licencji Creative Commons (CC BY-ND 4.0 Międzynarodowe). Zgłoszono: 21/04/2021. Zrecenzowano: 14/06/2021. Zaakceptowano do publikacji: 06/09/2021.
} 